v. 8, n. 2

Vitória-ES, Apr. - Jun. 2011.

p. $22-41 \quad$ ISSN 1808-2386 DOI: http://dx.doi.org/10.15728/bbr.2011.8.2.2

\title{
Trade credit profitability measurement: application in a wholesaler- distributor case
}

\author{
Dany Rogers Silva ${ }^{\dagger}$ \\ Federal University of Uberlândia \\ Karem Cristina de Sousa Ribeiro ${ }^{\Omega}$ \\ Federal University of Uberlândia \\ Hsia Hua Sheng ${ }^{*}$ \\ Getulio Vargas Foundation
}

\begin{abstract}
Credit extension evaluation is traditionally marked by customer's credit risk and his business potential, normally, the profitability that limit utilization may provide the company is not considered. Therefore, the purpose of this paper is to present a trade credit extension profitability measurement model. The literature used for the theoretical basis involves the profitability concept of the Theory of Restrictions (TOC) and the performance measure calculation as in RAROC model. Proposed model was applied in a wholesalerdistributor company and its results have enabled concluding that credit extension to customers rated as low risk is not always the most profitable option. The decision of companies that only take into consideration credit risk and customer size to set the credit limit may entail incorrect decisions that are decreasing the company's gain instead of increasing the wealth of its owners.
\end{abstract}

Keywords: Trade credit; credit risk; theory of restrictions; RAROC.

Author's correspondence*:

${ }^{\dagger}$ Master in Administration by the School of Management and Business of the Federal University of Uberlândia.

Link: Federal University of Uberlândia

Address: Rua Antonio Salviano de

Rezende. 1544, Apt. 01, Uberlândia -

Minas Gerais - MG - Brazil

CEP 38408-228

E-mail: Danyrogers@Pontal.Ufu.Br

Telephone: (34) 8836-9997

\footnotetext{
${ }^{\Omega}$ Post-Doctorate in Administration / Finances by the School of Economics, Administration and Accounting of the University of São Paulo - FEA/USP.

Link: Federal University of Uberlândia Address: Rua João Ramalho, 86, Apt. 100, Uberlândia - MG - Brazil CEP 38408-668

E-mail: Kribeiro@Ufu.Br

Telephone: (34) 3211-5197
}

\author{
${ }^{¥}$ Doctor In Administration (Finances) By \\ Getulio Vargas Foundation \\ Link: Getulio Vargas Foundation. \\ Address: Rua Itapeva, $474,8^{\text {th }}$ Floor, \\ Department CFC, São Paulo - SP- \\ Brazil - CEP 01332-000 \\ E-mail: Hsia.Sheng@Fgv.Br \\ Telephone: (11) 9558-2669
}

Editor's Note: This paper was accepted by Antonio Lopo Martinez. 


\section{INTRODUCTION}

The role of the financial manager is of fundamental importance in a context of constant changes, mainly in the functions of financial analysis and planning, investment decisions ad financing operations. This is because he is responsible for managing the entire organization's capital, due to its adequacy to the lowest possible risk level.

In a research conducted by Rajan and Zingales (1995) in G-7 countries, it was verified that credit stands for $11.5 \%$ (Germany) to 17\% (France) of all trade companies' liabilities. However, despite this importance and the great theoretical framework, about trade credit, little has been produced in terms of empirical tests, this, mainly, due to the scarcity of data.

In business organizations credit decision-making, generally, is based on credit risk and customer's business potential. Traditionally, for calculation of credit limit amount made available to customer, magnitude referentials are used (size classification): gross billing, share capital, purchase volume made on the market, etc; and credit risk. Therefore, a breakeven point is achieved in which credit extension is adequate to customer's risk profile and business potential.

Another important factor is that in these companies credit treatment as an investment is not always possible, mainly due to lack of tools. In this way, the hypothesis of the paper is that credit extension is made regardless if the limit amount used by the customer is being profitable or not to the granting company.

Profitability obtained by means of loans made by financial institutions is usually evaluated and there are financial models available to obtain this result, such as for example the RAROC model. However, in companies, when credit extension profitability calculation becomes necessary, there is no specific model that enables this measurement.

Thus, the following research problem comes up: How can trade credit profitability adjusted to credit risk be measured? What is the influence that this index can exert on credit extension decision-making process?

It is proposed for settling these issues the development of a model that will measure trade credit extension profitability adjusted to credit risk and, to this end, the Theory of Restriction (TOC) profitability concept and RAROC model (Risk-Adjusted Return on Capital) will be adopted for its calculation. The model application was performed in wholesaler-distributor branch company. 
For credit extension performance measurement, RAROC methodology adoption is justified, which relates return on capital offered by a transaction, or a deal, at the investment risk rate, in other words, risk-adjusted return on capital (CROUHY, GALAI and MARK, 2004).

With exclusion of this introduction, the article is structured on four sections: the second part will do the theoretical referential description; the purpose of part three will be to present proposed model; in the fourth section practical application of the model in a trade company of the wholesaler-distributor branch will be made; and section five will remain for final considerations of the paper.

\section{UNDERSTANDING CREDIT AND TOC}

Credit policy is divided, usually, into three parts: credit terms, credit analysis and collection policy. Credit also can be subdivided into bank credit and trade credit, in addition to credit for individuals and credit for legal entities. Each of these subdivisions has its particularities and treatment within literature. This paper is focused, only, on credit analysis and trade credit.

In the literature about trade credit, some theories that explain its existence and use prevail: financing motive, price description motive and transaction motive.

In financing motive credit providers have advantages over financial institutions, because trade credit allows them to have buyers and saving goods/values for subsequent redeployment of these goods on the market. Thence the justification for their use by trade companies (SCHWARTZ, 1974; PETERSON and RAJAN, 1997).

For price description motive, credit providers may offer to different customers several price levels, pricing the loan according to the operation risk, its due date and future agreement expectations with the customer (BRENNAN, MIKSIMOVIC and ZECHNER, 1988; PETERSON and RAJAN, 1997).

In trade credit transaction theory, since there are two transactions in the operation (of goods for the loan and the loan for payment), it is possible for buyers to organize their payments with greater certainty, separating them in cycles, eliminating the need for cash reserve for precaution (FERRIS, 1981; PETERSON and RAJAN, 1997). 
To Peterson and Rajan (1997), suppliers are better specialists than financial institutions in credit risk evaluation and control of their buyers' credit risk. But after all, what is credit risk? How is it measured?

The main purpose of credit analysis is to check the borrower's credit application compatibility with his financial and payment ability. In this credit policy stage risk assessment becomes one of its main analyses.

Credit risk can be defined as the credit grantor's likelihood of not receiving from debtor in stipulated term and conditions. According to Saunders (2000), credit risk assessment can be divided into traditional approaches: specialist systems, ratings and credit scoring models; and into new approaches to measure credit risk, highlighting portfolio risk models, such as KMV Credit Monitor model, J. P. Morgan CreditMetrics do, Credit Suisse CreditRisk + and RAROC model. Credit scoring, RAROC model and CreditRisk + will be important to this paper.

According to Altman and Haldeman (1995, p. 11, our translation), "the mistrust about subjective credit scoring consistence and a wish for mathematical 'definition' for such scorings $[\ldots]$ have generated interest in objective and reproducible models", such as credit scoring and CreditRisk+.

According to Saunders (2000), seven main reasons stand out for the sudden surge of interest in the development of credit risk measuring statistical models: structural bankruptcy increase; financial disintermediation; more competitive margins; declining and volatile values of collateral securities; extra-balance derivative growth; technology; and regulatory agency requirements.

And according to Altman and Saunders (1998), academicians and market practitioners have responded in the following manner: with the development of new and more sophisticated credit scoring systems; with a change of direction from individual credit risk analysis to the development of credit concentration risk measures; with the development of new credit risk pricing models (RAROC); and through the development of models for better extra-balance instrument measuring.

The purpose of credit scoring models is to define to likelihood of a customer becoming a defaulter, in other words, becoming a good or poor payer based on his characteristics. To that end, they assign statistically preset weights for certain attributes of credit applicants, so 
generating a score for each customer. If the customer has a higher score than cutoff point (minimum credit approval score), the credit must be approved, otherwise, it will be rejected.

These systems are divided into two categories: credit approval or credit scoring models and behavioral scoring models, also known as behavioral scoring (CAOUETTE et al, 2009). In credit scoring credit applications of new applicants are rated and behavioral scoring is a scoring system based on customer's behavioral analysis.

According to some authors (CAOUETTE et al, 2009; THOMAS et al, 2002; ALTMAN and SAUNDERS, 1998; PARKINSON and OCHS, 1998) the main advantages of credit scoring models are: it allows constant credit reviews; they tend to eliminate discriminatory credit extension practices; they are objective and consistent; they are simple, easy to interpret and install; it provides greater efficiency in treatment of outside data and extension processes; and it allows better organization of information. And its disadvantages are: degradation over the time if the population to apply the model is divergent from the original population when it was developed; too much user confidence; and lack of data and information causes problems in its utilization.

CreditRisk+, prepared by Credit Suisse in 1997, is "a default mode model" (SAUNDERS, 1998, p. 73), in other words, only the risk of default is modeled, "there is no rating change risk" (SECURATO, 2002, p. 286). In order to calculate risk in CreditRisk+, first an assessment of uncertainties is made (of the likelihood of default and intensity of losses), and only a later do these estimates generate loss distribution throughout the loan portfolio. When measuring loss percentage in each credit rating, loss distribution by default is found throughout the portfolio.

Profitability calculation proposed in the article will be based on RAROC model, this being a risk-adjusted return on invested capital methodology, which "reveals the necessary economic capital amount for each line of business, product or customer - and how these needs create total return on capital produced by the company" (CROUHY, GALAI and MARK, 2004, p.467). However, in this model the numerator is adjusted to catch expected with the transaction and the denominator to reflect the actual investment at risk.

Under RAROC point of view, measurement of return on capital invested in customer (please read in this case credit extended to customer) will be solely adjusted to credit risk. And under TOC point of view, in credit constraint conditions, adoption of profitability 
concept is justified by prioritizing credit extension to customers that provide greater return on investment (greater profitability in credit extension).

TOC (Theory of Constraints) premises were structured for production line problems, however, they quickly penetrated into the most varied areas of managerial knowledge and in different sectors (PADOVEZE, 2005). It generalizes optimization thinking in three principles:

1) The company is a system, a set of elements among which there is an interdependence relationship, where each element depends on the other somehow and, so, the overall system performance depends on joint efforts of all its elements;

2) The target of companies must be to make money, today and in the future; and

3) Every company, in the process of reaching its target, always presents one or more constraints, because, if it did not, its performance would be infinite.

A constraint in TOC is anything that limits better performance of a system, such as the weakest link of a chain, or something that we do not have enough (GOLDRATT, 1992). Therefore, standards, procedures, practices, supplier markets, equipment, materials, orders, people and credit may be a constraint.

Normally, constraints that are related to materials and production capacity are easily viewed, whereas behavior and management constraints, which also exist in companies, are not usually recognized as resource restrictors (GUERREIRO, 1999), as is the case of credit.

There is a general corporate decision-making process so that TOC will work and the five steps to this end are: identifying system constraints, deciding how to exploit system constraints, subordinating any other thing to the prior decision, increasing system constraints and, last, if in the previous steps a constraint is breached, return to step 1. (GOLDRATT, 1992)

TOC condemns the use of physical measures to measure performance, insisting on financial measures. There are three main key measures for TOC result measurement: gain $(\mathrm{G})$, inventories (I) and operating expenses (DO). Gain is the index by which the system generates money through sales, in other words, sales revenues (R) less fully variable cost (CTV). Inventories are all money invested in purchasing things we intend to sell and operating expenses are all money spent on converting inventory into gain.

It can be said that the purpose of TOC is to maximize gain while it minimizes inventories and operating expenses. To TOC all measures oriented to overall company 
performance measurement (target) are: net profit (LL), return on investment (RSI) and cash flow. Cash flow is considered as more a financial situation to company survival than, properly, a performance measure.

LL and RSI measures in TOC context can be observed below:

$$
\begin{aligned}
\mathrm{LL} & =\mathrm{G}-\mathrm{DO} \\
\mathrm{RSI} & =\frac{(\mathrm{G}-\mathrm{DO})}{\mathrm{I}}
\end{aligned}
$$

\section{TRADE CREDIT EXTENSION PROFITABILITY MODEL}

Traditional credit extension models generally take into consideration and/or give greater importance to customers' credit risk and his business potential, so, decision-making to grant or not credit and how much to grant is related to the rating of good/poor payer.

In order to have a basis of how flawed can credit extension decision be in this approach, consider the following decision. Two customer of an $\mathrm{X}$ trade company apply to increase their respective credit limits. Since these customers are in the same size bracket, the analysts then check the customer's risk class and find and customer Y has A rating and customer $\mathrm{Z}$ has $\mathrm{D}$ rating. Area analysts, more than quickly, approve a hither limit to customer $\mathrm{Y}$ in opposition to customer $\mathrm{Z}$.

However, when an analyzing both customers' purchasing history in the last years, it is verified that customer $Z$ essentially purchases electro-electronic products that yield an $18 \%$ average annual profitability to the company, and customer Y buys, practically, food products that contribute to the company with a $5 \%$ average annual profitability $5 \%$. Therefore, the following questions arise: how greater is customer $\mathrm{Z}$ credit risk in relation to customer $\mathrm{Y}$, which compensates a greater credit limit to him in relation to customer Z? Is credit extension made by taking into consideration his risk and size only the most adequate?

\subsection{The Formula Numerator}

The purpose of the paper to adjust RAROC to TOC gain concept, so that gain obtained by the difference between sales revenues and their fully variable costs $\left(\mathrm{CTV}_{\mathrm{i}}\right)$ will be reduced by expected loss with granted credit. We have that in RAROC numerator adjusted profit is obtained in a loan transaction by means of the sum of spread with fees and commission by subtracting expected losses and operating costs. 
The reason of the gain consideration (contribution margin) as a profitability measure, and not any other measure that builds fixed cost allocation, is justified by TOC. According to this theory, regardless or not of sale to customer, or accomplishing or not the transaction, fixed costs do not fail to exist and do not diminish, at least, in short term.

By following this logic, adjusted gain $\left(\mathrm{GA}_{\mathrm{i}}\right)$ as a result or credit risk would be:

$$
\mathrm{GA}_{\mathrm{i}}=\mathrm{R}_{\mathrm{i}}-\mathrm{CTV}_{\mathrm{i}}-\mathrm{P}_{\mathrm{i}}
$$

Where, $R_{i}$ would be revenues originating from sales, CTV fully variable costs and $P_{i}$ expected losses due to customer $i$ credit risk.

All Sales Revenues $\left(\mathrm{R}_{\mathrm{i}}\right)$ must enter gain calculation, irrespective of terms of payment no. Entrance into calculation of sales on installment only could be justified, because they would be the true investments made as a result of credit extension. However, customer relation obtained by credit extension also produces to granting company cash sales, and this relation, probably, would be interrupted, if the company stopped granting credit to customer, thus losing all source of gain originating from him (cash sales and sales on installments).

In proposed model, for $\mathrm{P}_{\mathrm{i}}$ estimate it will be considered that only the likelihood of default is modeled according to CreditRisk+, and that the company has a credit scoring system in which it is possible to obtain this likelihood per credit risk class. In this case, expected loss with customer can be estimated as follows (SECURATO, 2002):

$$
\mathrm{P}_{\mathrm{i}}=\mathrm{EDF}_{\mathrm{j}} \mathrm{x} \mathrm{LGD}_{\mathrm{j}}
$$

Where, $\mathrm{EDF}_{\mathrm{j}}$ represents the likelihood of customer's default given credit risk class $j$ where it is located; and $\mathrm{LGD}_{\mathrm{j}}$ (loss give default) represent loss given the customer's default (in monetary values) according to credit risk class $j$ where he is located, in other words, company net loss after discounting recovery rate.

This net loss, or $\mathrm{LGD}_{\mathrm{j}}$, will be calculated as follows:

$$
\operatorname{LGD}_{j}=E_{i} \times\left(1-T_{j}\right)
$$

Where, $E_{\mathrm{i}}$ is credit level practiced in the period, or sales on installment amount; and $\mathrm{T}_{\mathrm{j}}$ credit recovery rate in credit risk class $j$ where customer $i$ is located.

In order to calculate expected loss historic recovery rate can be measured having as a basis similar customer profiles, for example, historic recovery rate is measured by credit risk rating. So, the formula numerator would be: 


$$
\mathrm{GA}_{\mathrm{i}}=\mathrm{R}_{\mathrm{i}}-\mathrm{CTV}_{\mathrm{i}}-\left[\mathrm{EDF}_{\mathrm{j}} \times \mathrm{E}_{\mathrm{i}}\left(1-\mathrm{T}_{\mathrm{j}}\right)\right]
$$

If all company revenues originate from sales on installments, $R_{i}$ becomes equal to $E_{i}$.

\subsection{Formula Denominator}

Investment amount at risk used in RAROC model denominator is calculated by some VAR measure, and it "measures the worst loss expected over a certain time interval, under normal market conditions and within a certain level of confidence" (JORION, 1998, p. 82). Projections are made, generally, for a short period of time and confidence interval is $99 \%$ or $95 \%$.

Financial literature (JORION, 1998; CHRISTOFFERSEN, HAHN and INOUE, 1999; SAUNDERS, 2000; BAMS, JEHNERT and WOLFF, 2001; SECURATO, 2002; CROUHY, GALAI and MARK, 2004; AUSSENEGG and MIAZHYNSKAIA, 2006) discusses two approaches for VAR determination: (a) non-parametric (historical simulations); and (b) parametric.

In non-parametric approach, information is collected about levels affected by market variables every day and for a long period of the past. And in order to obtain VAR, the current financial position market value is recalculated for each market variable historical level, until finding the worst loss in desired confidence level (LEMGRUBER and OHANIAN, 2006).

In parametric analysis, asset and/or liability profit and/or loss distribution is estimated based on historical data, or determined a priori from a known likelihood distribution, such as normal or $t$-Student. In this case, estimates of averages and standard deviations are obtained, and if working with asset and/or liability portfolios, correlations of profit and/or loss series are. These parameters, used both in analytical manner and in a Monte Carlo simulation, allow calculating the worst hypothesis loss in desired confidence level of a financial position.

A parametric VAR measure will be adopted in this model. Equation 7 shows VAR calculation according to variables adopted in the model:

$$
\mathrm{VAR}_{\mathrm{i}}=\mathrm{PI}_{\mathrm{i}}-\mathrm{P}_{\mathrm{i}}
$$

Where, $\mathrm{P}_{\mathrm{i}}$ is expected loss and $\mathrm{PI}_{\mathrm{i}}$ is the worst loss in desired confidence level, and its calculation occurs as follows:

$$
\mathrm{PI} i=c \times \sigma_{\mathrm{j}} \times \mathrm{LGD}_{\mathrm{j}}
$$


Being that $\mathrm{LGD}_{\mathrm{j}}$ was already in Equation 5, $\mathrm{c}$ is $\mathrm{Z}$ standardized variable with normal distribution and $\sigma_{\mathrm{j}}$ represents the customer's likelihood of default standard deviation given credit risk class $j$ where it is located.

Loss standard deviation value would be obtained by binomial distribution approximation as follows:

$$
\sigma_{\mathrm{J}}=\sqrt{\mathrm{EDF}_{\mathrm{j}}\left(1-\mathrm{EDF}_{\mathrm{j}}\right)}
$$

In this way, the model general denominator expression will be:

$$
\mathrm{VAR}_{\mathrm{i}}=\left[c x \sqrt{\mathrm{EDF}_{\mathrm{j}}\left(1-\mathrm{EDF}_{\mathrm{j}}\right)} x \mathrm{E}_{\mathrm{i}}\left(1-\mathrm{T}_{\mathrm{j}}\right)\right]-\left[\mathrm{EDF}_{\mathrm{j}} x \mathrm{E}_{\mathrm{i}}\left(1-\mathrm{T}_{\mathrm{j}}\right)\right]
$$

\subsection{General Formula Philosophy and Adjustment Proposal}

Called RAGOC $\mathrm{i}_{\mathrm{i}}$ work (risk-adjusted gain on credit) proposed general decision measure formula is summarized as:

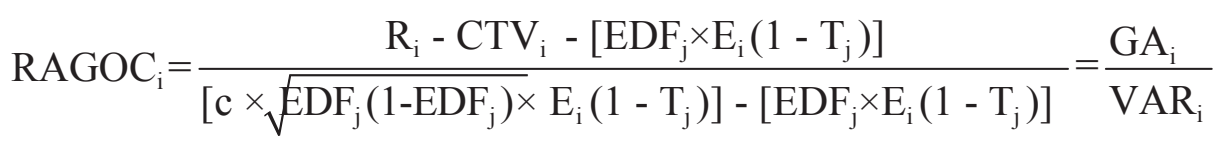

However, if it is not modeled in variable $T_{j}$ or $E_{i}$, customer's debt payment time factor to the company may impact decision-making based on $\mathrm{RAGOC}_{\mathrm{i}}$ measure.

For example, assuming that customer Oliveira Mercearia Ltda and Supermercado Pet Ltda are similar (credit risk, credit limit, average negotiation, etc) and with the same RAGOC $_{\mathrm{i}}$ estimate, except for the fact that average reception time (PMR) of customer Oliveira is 30 days and customer Supermercado Pet it is 60 days. In this case, In this case, considering the two-month period, obtained gain with customer Oliveira might be increased without additional risk, because it is enough to reapply gain for another 30 days at risk-free rate $\left(\mathrm{I}_{\mathrm{F}}\right)$. A natural and simple adjustment proposal so that $\mathrm{RAGOC}_{\mathrm{i}}$ of both customers to become comparable would be to transform this rate to reflect the company's money opportunity. To this end, it is enough to discount $\mathrm{RAGOC}_{\mathrm{i}}$ rate by a risk-free rate.

Considering an annual horizon (360 days), RAGOC $_{\mathrm{i}}$ measure, discounted at the cost to invest risk-free would be as follows:

$$
\operatorname{RAGOC}^{\prime} i=\frac{\left(1+\text { RAGOC }_{i}\right)}{\left(1+\mathrm{I}_{\mathrm{F}}\right)^{\frac{\text { PMR }_{i}}{360}}}
$$


Where, RAGOC' ${ }_{\mathrm{i}}$ was freely called adjusted risk-adjusted gain on credit of customer $i$; RAGOC $\mathrm{i}_{\mathrm{i}}$ is the risk-adjusted gain on credit (equation 11); $\mathrm{PMR}_{\mathrm{i}}$ is average reception time with customer $i$ in days; $\mathrm{I}_{\mathrm{F}}$ is the annual risk-free rate (and SELIC, CDI or Savings may be used). Company average reception time may be obtained by periodic balance sheets through the following formulation.

$$
\mathrm{PMR}_{\mathrm{i}}=360[\mathrm{DR} / \mathrm{V}]=360 / \mathrm{G}_{\mathrm{i}}
$$

Where, DR represents trade bill receivable average for analyzed year; V is sales volume for analyzed year; and $\mathrm{G}_{\mathrm{i}}$ represents the rotation (turnover) of trade bills receivable (V/DR). Equation 13 shows the company's $\mathrm{PMR}_{\mathrm{i}}$ and not or a specific customer, so, in order to calculate of a customer separately, terms of its purchases must be analyzed and weigh by the value of their titles.

However, $\mathrm{PMR}_{\mathrm{i}}$ as traditionally calculated, may result in serious problems in this proposal. In practice, trade companies grant a "revolving predetermined credit" to their customers: any purchase that does not exceed credit limit, in general, is automatically approved. If customer A buys on average with 7.5-day term and has $\mathrm{R} \$ 10$-thousand reais credit limit, it means that it can buy around $\mathrm{R} \$ 40$ thousand reais from the company in the month without necessarily going through credit analysis, in other words, it a 4-time turnover the limit granted over the month. If another customer B has R\$20-thousand reais limit and seldom buys more than $\mathrm{R} \$ 5$ thousand reais, its turnover is 0,25 .

In any situation, the investment that is exposed is the granted credit limit: customer A with $\mathrm{R} \$ 10$-thousand reais limit and fully using it may buy up to this amount and is in default and customer B, even with 20-thousand reais limit and not exceeding this threshold, may shop in this amount and fail to pay it fully. Under this perspective, knowledge of "revolving credit" turnover becomes of fundamental importance to extract information from $\mathrm{PMR}_{\mathrm{i} .}$. To the model this variable no longer has traditional meaning, but it will translate the time in which credit limit becomes, once again, available to be used by customer. In these conditions, assuming annual sales data, we have:

$$
\underset{\mathrm{i}}{\mathrm{PMR}^{\prime}}=360\left\lfloor\frac{\mathrm{Li}}{\mathrm{E}_{\mathrm{i}}}\right\rfloor
$$

Where, PMR' ${ }_{i}$ represents average customer's $i$ credit limit restoration in days; $\mathrm{L}_{\mathrm{i}}$ is the credit limit granted to customer $i$; $\mathrm{E}_{\mathrm{i}}$ is practiced credit level, or sales on installment amount, by customer $i$. The relevant comparison to be made based on RAGOC' ${ }_{\text {I }}$ measure is between 
customers with different risks, because otherwise it would be enough to analyze the gain rate ( $\mathrm{G}$ in \%) average credit limit restoration time (equation 14). To this end, consider that all purchases are on installment so that $\mathrm{E}_{\mathrm{i}}=\mathrm{R}_{\mathrm{i}}$. In these terms, after equation 11 rearrangement, we have the following formula:

$$
\operatorname{RAGOC}_{i}=\frac{\frac{R_{i}-C_{T V}}{R_{i}}-\left[E D F_{j} \times\left(1-T_{j}\right)\right]}{\left[c \times \sqrt{\operatorname{EDF}_{j}\left(1-E_{j}\right)} \times\left(1-T_{j}\right)\right]-\left[E D F_{j} \times\left(1-T_{j}\right)\right]}
$$

Note that the second term of the numerator and the second term of the denominator are equal for all customers in the same risk bracket $\mathrm{j}$. What differentiates RAGOCi measure without adjustment, in this case, is solely the gain rate [(Ri - CTVi )/ Ri] (See equation 3). When making the adjustment proposed in equation 12, the point of differentiation is variable PMR'i (equation 14). Thus, it can be inferred that the main determining factors of customers' profitability are the gain rate and credit revolving limit turnover $\left(\mathrm{E}_{\mathrm{i}} / \mathrm{L}_{\mathrm{i}}\right)$.

\subsection{Decision-making with RAGOC}

Once RAGOC' ${ }_{i}$ measure (Equation 12) is estimated for each company customer, how to proceed with decision-making about credit extension having proposed model as a basis? The work is proposed in three decision-making manners from the model:

1) Once credit profitability of each customer is measured, a natural analysis becomes to compare this profitability among customers by risk rating (equal and different from each other).

2) From RAGOC' ${ }_{i}$ measure estimate adopted for each customer, they can be classified by profitability ratings. So, from an aggregate analysis of the entire company, a distribution of RAGOC' ${ }^{\prime}$ measure probabilities can be calculated, and propose profitability ratings. This classification is flexible enough in order to contemplate several proposals: 1) classification of independent customers from degree of risk; 2) categorization of customers by risk bracket; 3 ) in possession of RAGOC' ${ }_{I}$ rate likelihood distribution, under hypothesis 1 and 2, we have the option of segregating this distribution: a) median; b) average; c) quartiles; d) decis; or e) another statistical classification. We would also have the option of segregating likelihood distribution in order to classify customers below and over a barrier rate.

3) From RAGOC' ${ }_{i}$ and credit risk classification, a joint classification by profitability and credit risk is made. Thus, assuming that the company has a risk 
classification system, this classification can be added to any other obtained in proposal 2.

\section{PRACTICAL APPLICATION OF THE MODEL}

This section will apply presented model in a real trade company of wholesalerdistributor line. In order to estimate the relevant variables of the model, a database of 9,381 active customers was used. For the sample survey, company active customers with a longer than 6 month history were selected.

This amount has statistical validity because it is representative of total company active customers and is minimum 6-month history period is justifiable because this is the necessary time for company behavioral scoring time.

\subsection{Decision-making according to Proposal 1}

For application of this proposal four company customers with distinct sizes and lines of business were selected for detailing RAGOC measure calculation (equation 11 and 12): Empreiteira Simão, Informática real time, Mercearia do João and JJRR Eletrodomésticos. From this time on, equation 11 will be named RAGOC only and equation 12 RAGOC'.

By the company's credit scoring system the four selected customers had the following scoring: Empreiteira Simão and Informática real time in AAA bracket, Mercearia do João in rating A and JJRR Eletrodomésticos in rating B. Loss likelihood in each rating is: $0.0060 \%$ for AAA bracket, $0.0814 \%$ in rating A and $0.3108 \%$ for B bracket. Considering that all sales were made on installments table 1 shows adjusted gain calculations (see equation 3 ) of these four customers.

TABLE 1 - ADJUSTED CUSTOMERS' GAIN

\begin{tabular}{lllllc}
\hline \multicolumn{1}{c}{ Customer } & Revenues & \multicolumn{1}{c}{ CTV } & G (in reais) & G (in \%) \\
\hline Empreiteira Simão & $\mathrm{R} \$ 4.742,42$ & $\mathrm{R} \$ 4.649,41$ & $\mathrm{R} \$ 93,01$ & 1,96 \\
Informática real time & $\mathrm{R} \$ 109.742,08$ & $\mathrm{R} \$ 109.160,28$ & $\mathrm{R} \$ 581,80$ & 0,53 \\
Mercearia do João & $\mathrm{R} \$ 77.204,90$ & $\mathrm{R} \$ 72.394,78$ & $\mathrm{R} \$ 4.810,12$ & 6,23 \\
JJRR Eletrodomésticos & $\mathrm{R} \$ 21.121,38$ & $\mathrm{R} \$ 17.038,26$ & $\mathrm{R} \$ 4.083,12$ & 19,33 \\
\hline Source: Prepared
\end{tabular}

Source: Prepared by authors.

By multiplying risk bracket loss likelihood by total sales on installments of each customer, we obtain expected loss amount for each customer (equation 4 and 5). By subtracting this $\mathrm{G}$ amount (in reais) from Table 1 we have adjusted gain to credit risk for each customer (equation 6), in other words, the formula numerator. Table 2 shows mentioned calculations. 
TABLE 2 - ADJUSTED GAIN TO CUSTOMERS' CREDIT RISK

\begin{tabular}{lccc}
\hline & Customer & Loss & \multicolumn{1}{c}{ GA } \\
\hline Empreiteira Simão & $\mathrm{R} \$ 0,28$ & $\mathrm{R} \$$ & 92,73 \\
Informática real time & $\mathrm{R} \$ 6,54$ & $\mathrm{R} \$$ & 575,26 \\
Mercearia do João & $\mathrm{R} \$ 62,86$ & $\mathrm{R} \$ 4.747,26$ \\
JJRR Eletrodomésticos & $\mathrm{R} \$ 65,65$ & $\mathrm{R} \$ 4.017,48$ \\
\hline
\end{tabular}

Source: Prepared by authors.

It becomes necessary to establish the confidence level and standardized variable $\mathrm{Z}$ in order to calculate the model's denominator. For confidentiality reasons, recovery rate was not informed at company request, therefore, it is not possible to inform its net loss (LGD). However, it is known that the company seeks not to lose more than $0.15 \%$ of sales, generating a $99.85 \%$ confidence level. Therefore, $\mathrm{Z}$ value, according to normal distribution, is 2.9677 . Through equation 9 we have standard deviation values for each customer: Empreiteira Simão and Informática real time (1.0409\%); Mercearia do João (3.8448\%); and JJRR Eletrodomésticos (7.4960\%). Expected loss having already been calculated, $c$ stipulated and standard deviation informed before, by equation 8 unexpected loss for each customer is calculated. Having calculated expected loss and unexpected loss it is possible to calculate VAR (See equation 11 and 7), or the formula denominator, consequently, profitability value adjusted to credit risk for each customer.

TABLE 3 - CUSTOMERS' RAGOC

\begin{tabular}{llllc}
\hline \multicolumn{1}{c}{ Customer } & \multicolumn{1}{c}{ PI } & \multicolumn{2}{c}{ VAR } & RAGOC (in \%) \\
\hline Empreiteira Simão & $\mathrm{R} \$ 80,57$ & $\mathrm{R} \$ 80,29$ & 115,49 \\
Informática real time & $\mathrm{R} \$ 1.864,55$ & $\mathrm{R} \$ 1.858,00$ & 30,96 \\
Mercearia do João & $\mathrm{R} \$ 4.845,09$ & $\mathrm{R} \$ 4.782,23$ & 99,27 \\
JJRR Eletrodomésticos & $\mathrm{R} \$ 2.584,28$ & $\mathrm{R} \$ 2.518,64$ & 159,51 \\
\hline
\end{tabular}

Source: Prepared by authors.

Definitive proposed profitability measure value (equation 12) is obtained with average credit restoration time adjustment (PMR'). In this example, the ratio $\left(\mathrm{L}_{\mathrm{i}} / \mathrm{E}_{\mathrm{i}}\right)$ of equation 13 must be multiplied by 180 , since we are working with a six-month history. At last, the $11.25 \%$ p.a. value of SELIC rate was used as risk-free rate for RAGOC measure adjustment. In table 4 we have RAGOC' calculation.

TABLE 4 - CUSTOMERS' RAGOC'

\begin{tabular}{lcccc}
\hline \multicolumn{1}{c}{ Customer } & $\mathrm{L}$ & $\mathrm{G}_{\mathrm{i}}$ & $\mathrm{PMR}^{\prime}$ & RAGOC' (in \%) $^{\text {\% }}$ \\
\hline Empreiteira Simão & $\mathrm{R} \$ 12.116,86$ & 0,39 & 459,90 & 88,05 \\
Informática real time & $\mathrm{R} \$ 48.000,00$ & 2,29 & 78,73 & 27,94 \\
Mercearia do João & $\mathrm{R} \$ 10.000,00$ & 7,72 & 23,31 & 97,90 \\
JJRR Eletrodomésticos & $\mathrm{R} \$ 7.000,00$ & 3,02 & 59,66 & 154,97 \\
\hline
\end{tabular}

Source: Prepared by authors.

Table 5 shows a summary of analyzed customers' profitability rates and from DRE analysis and wholesaler-distributor's Balance sheet, we arrived at its RSI overall performance 
measure that was around $34 \%$ in the last six months. When this measure is adjusted by average reception time we have a $33.63 \%$ figure.

TABLE 5 - CUSTOMER RATE SUMMARY

\begin{tabular}{lcccc}
\hline \multicolumn{1}{c}{ Customer } & Rating & GA (\%) & RAGOC (in \%) & RAGOC' (in \%) \\
\hline Empreiteira Simão & AAA & $1,96 \%$ & 115,49 & 88,05 \\
Informática real time & AAA & $0,53 \%$ & 30,96 & 27,94 \\
Mercearia do João & A & $6,23 \%$ & 99,27 & 97,90 \\
JJRR Eletrodomésticos & B & $19,33 \%$ & 159,51 & 154,97 \\
\hline
\end{tabular}

Source: Prepared by authors.

In a decision situation on credit limit increase of these four customers, the traditional credit analysis view would indicate to grant a greater limit to Empreiteira Simão or Informática real time because they have the lowest credit risk, considering that their sizes are similar. However, through table 5 it is possible o reach some conclusions that contradict this view:

1) Even Informática real time having the lowest risk level (AAA), when compared to its credit extension profitability by proposed model (RAGOC or RAGOC') with the company's overall performance measure (RSI), it is not viable not even if the company grants it a loan, because its $30.96 \%$ RAGOC or its $27.94 \%$ RAGOC' is lower than the company's $33.63 \% \mathrm{RSI}$.

2) The company with the highest credit risk, JJRR Eletrodomésticos in rating $B$, is the company that has the highest profitability measures, both RAGOC and RAGOC'. Therefore, considering the sizes of all company equal, it should be the company with the highest credit limit, unlike the traditional view that would grant higher volumes to Informática real time and Empreiteira Simão.

\subsection{Decision-Making According to Proposal 2}

In a first moment, it becomes interesting to show how the definitive profitability measure (RAGOC') behaves in relation to the company's risk classes. Table 6 presents how willing customers are in relation to credit risk ratings, as well as some descriptive statistics of RAGOC' variable. When analyzing the number of customers in each risk rating and their frequency, it is evidenced that a large part (approximately 74\%) have a low degree of risk (AAA and AA). The closeness of averages and medians within risk classes shows that, internally, RAGOC' variable distribution is relatively symmetrical.

By means of RAGOC' variable standard deviation in each risk class, it is possible to obtain the variation coefficient described in Table 6 . This measure allows identifying 
homogeneity within each risk class. It is evidenced that AAA customers' variation coefficient is low in comparison to other risk ratings, with growth trend up to A rating, in order to reduce later and grow again to class B. From class CCC, heterogeneity within the class increases when compared to rating AAA. This information demonstrates that lowest risk customers (AAA to A) are more homogenous in terms of profitability when comparing them to the highest risk customers ( $\mathrm{CC}$ and $\mathrm{C})$.

TABLE 6 - DESCRIPTIVE STATISTICS OF RAGOC' SAMPLE BY RISK RATING

\begin{tabular}{cccccc}
\hline Risk Rating & $\begin{array}{c}\text { No. } \\
\text { Customers }\end{array}$ & $\begin{array}{c}\text { Frequency } \\
(\%)\end{array}$ & Average & Median & $\begin{array}{c}\text { Variation } \\
\text { Coeff. }\end{array}$ \\
\hline AAA & 3.904 & $41,60 \%$ & $422,82 \%$ & $427,52 \%$ & $54,43 \%$ \\
AA & 3.073 & $32,80 \%$ & $231,57 \%$ & $238,72 \%$ & $59,32 \%$ \\
A & 1.141 & $12,20 \%$ & $113,16 \%$ & $118,95 \%$ & $69,11 \%$ \\
BBB & 410 & $4,40 \%$ & $108,57 \%$ & $108,45 \%$ & $56,88 \%$ \\
BB & 194 & $2,10 \%$ & $107,34 \%$ & $112,85 \%$ & $51,52 \%$ \\
B & 274 & $2,90 \%$ & $73,41 \%$ & $69,58 \%$ & $73,98 \%$ \\
CCC & 156 & $1,70 \%$ & $43,14 \%$ & $44,31 \%$ & $65,17 \%$ \\
CC & 196 & $2,10 \%$ & $20,97 \%$ & $21,45 \%$ & $70,17 \%$ \\
C & 33 & $0,40 \%$ & $11,67 \%$ & $11,04 \%$ & $164,68 \%$ \\
\hline Total & 9.381 & $100,00 \%$ & $275,89 \%$ & $240,74 \%$ & $91,58 \%$ \\
\hline
\end{tabular}

Source: Prepared by authors.

There could be several profitability rating proposals: from statistical measure-based categorization to subjective classification with theoretical base a priori. In order to simplify understanding, it is proposed in this application to divide RAGOC' variable distribution into decis according to the amount of the sample customers. In table 7 we have that ratings follow the traditional nomenclature (by letters) and the classification score in each rating is based on RAGOC' variable value: as an example, values with RAGOC' over $581.57 \%$ are classified in AAA, and customers below $34.09 \%$ are classified in D. Note that at ends, in AAA and D, profitability distributions are not so symmetrical as in classifications by credit risk.

TABLE 7 - SAMPLE PROFITABILITY RATING

\begin{tabular}{cccccc}
\hline $\begin{array}{c}\text { Profitability } \\
\text { Rating }\end{array}$ & RAGOC' Bracket & Average & Median & No. Customers & Frequency $(\%)$ \\
\hline AAA & $>581,57 \%$ & $715,44 \%$ & $680,17 \%$ & 938 & $10,0 \%$ \\
AA & $581,57 \%-456,43 \%$ & $514,85 \%$ & $513,14 \%$ & 938 & $10,0 \%$ \\
A & $456,42 \%-370,07 \%$ & $411,48 \%$ & $409,88 \%$ & 938 & $10,0 \%$ \\
BBB & $370,06 \%-300,39 \%$ & $335,05 \%$ & $336,22 \%$ & 938 & $10,0 \%$ \\
BB & $300,38 \%-240,78 \%$ & $270,19 \%$ & $270,42 \%$ & 938 & $10,0 \%$ \\
B & $240,77 \%-182,81 \%$ & $211,65 \%$ & $211,32 \%$ & 938 & $10,0 \%$ \\
CCC & $182,80 \%-135,39 \%$ & $158,84 \%$ & $158,64 \%$ & 938 & $10,0 \%$ \\
CC & $135,38 \%-88,85 \%$ & $111,83 \%$ & $111,62 \%$ & 938 & $10,0 \%$ \\
C & $88,84 \%-34,09 \%$ & $61,67 \%$ & $61,95 \%$ & 938 & $10,0 \%$ \\
D & $<34,09 \%$ & $-32,03 \%$ & $1,79 \%$ & 938 & $10,0 \%$ \\
\hline Total & & $275,89 \%$ & $240,74 \%$ & 9.380 & $100,0 \%$ \\
\hline
\end{tabular}

Source: Prepared by authors. 
From the company's financial statements, it is verified that overall performance measure (RSI) was $33.63 \%$ in the last six months. This information translates that the entire inventory at risk in the company generates gain at a $33.63 \%$ rate. So, decision-making on credit by using this profitability rating (Table 6) could be from not extending limit to customers in ratings $\mathrm{D}$, taking into account that these customers are with a lower return than obtained by the company through its other assets.

The logic of this conclusion does not suggest stopping selling on installments to customers below the barrier rate, but in the following meaning: in credit constraint conditions, customers below the barrier rate will always be the last on the list of priorities for extension.

\subsection{Decision-Making According to Proposal 3}

A joint classification that takes into account credit risk and profitability may undergo as many variations as there are individual classification proposals. As an extension of profitability classification by decis and discussed in the previous section, we have Table 8 , where absolute cross frequency between risk and profitability ratings are evidenced.

Table 8 brings decisive information for credit decision-making: lowest risk customers are those presenting greater profitability, however, this statement is not a general rule. There low credit risk customers presenting low or even negative profitability, as well as there are high risk and good profitability customers. When very low risk customers (AAA) are analyzed, it is noticed that there are 94 customers with profitability in classification C (low) and 174 with classification D (negative).

TABLE 8 - PROFITABILITY MATRIX AND RISK OF SAMPLE CUSTOMER AMOUNT

\begin{tabular}{cccccccccc}
\hline Profitability & \multicolumn{1}{c}{ Risk Rating } \\
Rating & $A A A$ & $A A$ & $A$ & $B B B$ & $B B$ & $B$ & $C C C$ & $C C$ & $C$ \\
\hline$A A A$ & 915 & 22 & 0 & 0 & 0 & 1 & 0 & 0 & 0 \\
$A A$ & 824 & 114 & 0 & 0 & 0 & 0 & 0 & 0 & 0 \\
$A$ & 637 & 299 & 2 & 0 & 0 & 0 & 0 & 0 & 0 \\
$B B B$ & 438 & 492 & 7 & 0 & 1 & 0 & 0 & 0 & 0 \\
$B B$ & 300 & 589 & 42 & 6 & 1 & 0 & 0 & 0 & 0 \\
$B$ & 219 & 504 & 163 & 37 & 14 & 2 & 0 & 0 & 0 \\
$C C C$ & 176 & 361 & 251 & 98 & 40 & 12 & 0 & 0 & 0 \\
$C C$ & 127 & 263 & 275 & 122 & 75 & 68 & 8 & 0 & 0 \\
$C$ & 94 & 196 & 224 & 102 & 40 & 153 & 95 & 33 & 1 \\
$D$ & 174 & 233 & 177 & 45 & 23 & 38 & 53 & 163 & 32 \\
\hline Total & 3.904 & 3.073 & 1.141 & 410 & 194 & 274 & 156 & 196 & 33 \\
\hline
\end{tabular}

Source: Prepared by authors.

Considering that the target of studied company is a $0.15 \%$ net loss, customers above B risk rating would have approved credit, so totaling 659 customers. However, a large part of 
customers (above $\mathrm{C}$ rating) are with higher profitability than the company's RSI (33.63\%), which allows concluding that they could have approved credit even being in a non-acceptable risk level by it.

Table 9 supplements the preceding information by segregating RAGOC' variable average by profitability and risk brackets. The presence of some negative profitability is observed in this Table. Thus, overall system performance can be optimized by excluding customers that present negative gain.

TABLE 9 - PROFITABILITY MATRIX AND RAGOC' AVERAGE RISK

\begin{tabular}{|c|c|c|c|c|c|c|c|c|c|}
\hline \multirow{2}{*}{$\begin{array}{l}\text { Profitability } \\
\text { Rating }\end{array}$} & \multicolumn{9}{|c|}{ Risk Rating } \\
\hline & $A A A$ & $A A$ & $A$ & $B B B$ & $B B$ & $B$ & $C C C$ & $C C$ & $C$ \\
\hline$A A A$ & $716,48 \%$ & $677,04 \%$ & & & & $611,71 \%$ & & & \\
\hline$A A$ & $516,47 \%$ & $503,13 \%$ & & & & & & & \\
\hline$A$ & $413,98 \%$ & $406,19 \%$ & $406,16 \%$ & & & & & & \\
\hline$B B B$ & $337,12 \%$ & $333,24 \%$ & $335,29 \%$ & & $317,52 \%$ & & & & \\
\hline$B B$ & $271,69 \%$ & $270,05 \%$ & $263,91 \%$ & $256,15 \%$ & $250,60 \%$ & & & & \\
\hline$B$ & $213,27 \%$ & $213,62 \%$ & $206,02 \%$ & $205,02 \%$ & $200,30 \%$ & $199,00 \%$ & & & \\
\hline$C C C$ & $159,50 \%$ & $160,43 \%$ & $158,03 \%$ & $156,49 \%$ & $155,03 \%$ & $150,05 \%$ & & & \\
\hline$C C$ & $112,61 \%$ & $112,20 \%$ & $112,14 \%$ & $111,19 \%$ & $113,43 \%$ & $108,50 \%$ & $100,21 \%$ & & \\
\hline$C$ & $62,66 \%$ & $62,25 \%$ & $64,17 \%$ & $63,35 \%$ & $66,92 \%$ & $62,65 \%$ & $55,07 \%$ & $41,64 \%$ & $47,12 \%$ \\
\hline$D$ & $-105,08 \%$ & $-53,15 \%$ & $-20,27 \%$ & $0,66 \%$ & $2,92 \%$ & $8,98 \%$ & $13,12 \%$ & $16,79 \%$ & $10,56 \%$ \\
\hline Total & $422,82 \%$ & $231,57 \%$ & $113,16 \%$ & $108,57 \%$ & $107,34 \%$ & $73,41 \%$ & $43,14 \%$ & $20,97 \%$ & $11,67 \%$ \\
\hline
\end{tabular}

Source: Prepared by authors.

\section{FINAL CONSIDERATIONS}

The purpose of the work was to present trade credit extension profitability measurement having as a theoretical foundation the Theory of Constraints (TOC). By TOC theoretical grounding that the main purpose of an organization is to make money today and always, it was possible to direct the study to calculation of an overall performance measure for the credit decision-making process. Thereby it is sought to cause companies to see the need for them to get out of the credit risk only when extending credit, to the profitability focus of this extension, in other words, "get out of the worlds of risk and go into the world of gains".

By means of calculating credit extension index for a company in the wholesalerdistributor branch, the conclusion was reached that, in some situations, extension to low-risk customers was not viable because the extension profitability was low when this index was compared to the return on the company's investment.

The contrary also proved to be true, namely, high-risk customers with high credit extension profitability rates, but that were not receiving credit from the company, or it was 
restricting offered amount. In this situation, credit extension in terms of profitability would be viable for these high-risk customers, while when verifying their risk only it would not be possible to reach this same conclusion.

By practical application of the model it was possible to conclude that credit extension decision must not only consider credit risk and the size of the customer, because it may be decreasing the wealth of its shareholders. Therefore, joint credit extension analysis by credit risk classification and the profitability index of the extension becomes necessary and fundamental so that companies will make more correct financial decisions and that these decisions will bring wealth increase to their shareholders.

And as shown, it is also possible to conclude that once the profitability index is calculated, it may provide the credit manager with an important point in the credit extension decision-making process. In some cases this indicator may have a more relevant contribution in the decision-making process than other analyzed factors, mainly when a customer has a high risk and high profitability, or low risk and negative/low profitability.

\section{REFERENCES}

ALTMAN, E. I.; HALDEMAN, R. Corporate credit scoring models: approaches and tests for successful implementation, Journal of commercial lending, p. 10-22, May 1995.

ALTMAN, E. I.; SAUNDERS, A. Credit risk measurement: developments over the last 20 years. Journal of banking \& finance, v. 21, p. 1721-1742, 1998.

AUSSENEGG, W.; MIAZHYNSKAIA, T. Uncertainty in value-at-risk estimates under parametric and non-parametric modeling, Financial Markets and Portfolio Management, v. 20, n. 3, p. 243-264, September 2006.

BAMS, D.; LEHNERT, T.; WOLFF, C. C. P. An evaluation framework for alternative VAR models, Journal of International Money and Finance, v. 24, n. 6, p. 944-958, October 2005.

BRENNAN, M. J.; MIKSIMOVIC, V. ZECHNER, J. Vendor Financing, The journal of finance, v. 43, n. 5, p. 1127-1141, Dec. 1988.

CAOUETTE, J. B.; ALTMAN, E.; NARAYANAN, P.; NIMMO, R. W. Gestão do risco de crédito: o próximo grande desafio financeiro. 2. ed., Rio de Janeiro: Qualitymark, SERASA, 2009.

CHRSTOFFERSEN, P.; HAHN, J.; INOUE, A. Testing, comparing, and combining value-atrisk measures. Working Paper, University of Michigan, October 1999. Available at: $<$ http://www.ssrn.com>. Access on 04/06/2010. 
CROUHY, M.; GALAI, D.; MARK, R. Gerenciamento de risco: abordagem conceitual e prática: uma visão integrada dos riscos de crédito operacional e de mercado. Rio de Janeiro: Qualitymark; São Paulo: Serasa, 2004.

FERRIS, J. S. A Transactions Theory of Trade Credit Use, Quarterly Journal of Economics, v. 96, n. 2, p. 243-270, May 1981.

GOLDRATT, E. M. A síndrome do palheiro: garimpando informação num oceano de dados. São Paulo: Educador, 1992.

GUERREIRO, R. A meta da empresa: seu alcance sem mistérios. São Paulo: Atlas, 1999.

JORION, P. Value at risk: A nova fonte de referência para o controle do risco de mercado. São Paulo: BM\&F, 1998.

LEMGRUBER, E. J.; OHANIAN, G. O modelo de projeção de volatilidade do riskmetricsTM e a hipótese de distribuição normal condicional para alguns fatores de risco no Brasil. In: LEMGRUBER, E. J. CARVALHAL DA SILVA, A. L.; LEAL, R. P. C.; COSTA JUNIOR, N. C. A. Gestão de risco e derivativos: aplicações no Brasil. São Paulo: Atlas, 2006.

MELTZER, A. H. Mercantile credit, monetary policy and size of firms, The review of Economics and Statistic, v. 42, n. 4, p. 429-437, Nov. 1960.

PADOVEZE, C. L. Controladoria Avançada. São Paulo: Pioneira Thomson Learning, 2005.

PARKINSON, K. L.; OCHS, J. R. Using credit screening to manage credit risk, Business Credit, p. 23-27, March 1998.

PETERSON, M .A; RAJAN, R. G. Trade credit: theories and evidence, The review of financial studies, v. 10, n. 3, p. 661-691, Autumn, 1997.

RAJAN, R. G; ZINGALES, L. What do we know about capital structure? Some evidence from international data, The journal of finance, v. 50, n. 5, p. 1421-1460, Dec., 1995.

SAUNDERS, A. Medindo o risco de crédito: novas abordagens para value at risk e outros paradigmas. Rio de Janeiro: Qualitymark, 2000.

SCHRICKEL, K. W. Análise de crédito: concessão e gerência de empréstimos. 2. ed., São Paulo: Atlas, 1995.

SCHWARTZ, R. A. An economic model of trade credit, The journal of financial and quantitative analysis, v. 9, n. 4, p. 643-657, Sep. 1974.

SECURATO, J. R. (Coord.). Crédito: análise e avaliação do risco - pessoas físicas e jurídicas. São Paulo: Saint Paul, 2002.

SMITH, J. K. Trade credit and informational asymmetry, The journal of finance, v. 42, n. 4, p. 863-872, Sep. 1987.

THOMAS, L. C.; EDELMAN, D. B.; CROOK, J. N. Credit scoring and its applications. Philadelphia: SIAM, 2002. 